\title{
10.53116/pgaflr.2018.2.7
}

\section{The Constitution and Public Administration}

\author{
Aksana Shupitskaya*
}

\begin{abstract}
* Aksana Shupitskaya, Candidate of Law, Associate Professor of Constitutional Law, Department of International Law, Faculty of Law, Yanka Cupala Grodno State University, Belarus. The author specialises in constitutional law. She is the author of several books and articles in prestigious journals. She is a member of the Centre of Information and Organization of Public Finances and Tax Law Research in Central and Eastern Europe. (e-mail: oshupitskaya@mail.ru)
\end{abstract}

\begin{abstract}
The article is devoted to the analysis of the ratio of public administration and the Constitution. At the same time, under public administration, the author understands the activities of state bodies and their officials to transform social relations for the benefit of society and the state. And under the Constitution - the Basic Law (or the sources of law) of the state and society, containing the system of constitutional principles and norms and ensuring the achievement and preservation of constitutional values.
\end{abstract}

The main task of the author is to confirm that the Constitution is the basis and at the same time the framework of public administration, and the constitutional values are the purpose of its implementation.

To reveal the question, such general scientific methods of cognition were used as analysis, synthesis and generalisation. Comparative legal, concrete sociological research methods, interdisciplinary and complex approaches attracted the attention of the researcher in the study of the problem.

Keywords: public administration; Constitution; constitutional principles and norms

\section{Introduction}

The main purpose of the author is to confirm that the Constitution, i.e. constitutional principles and constitutional norms, are the basis and at the same time the framework of public administration. The essence of public administration is to ensure constitutional values.

To reveal the question, such general scientific methods of cognition were used as analysis, synthesis and generalisation. Comparative legal, concrete sociological research methods, interdisciplinary complex approaches attracted the attention of the researcher in the study of the problem.

The author relied on the works of such researchers in the field of public administration as Tikhomirov Yu. A., ${ }^{1}$ Vasilenko I. A., ${ }^{2}$

Litvak B. ${ }^{3}$ and specialists in the sphere of constitutional law - Avakyan S. A., ${ }^{4}$ Bondar N. S., ${ }^{5}$ I. Kravets I. A., ${ }^{6}$ Crosse V. I. ${ }^{7}$ and Liverovskii A. A. ${ }^{8}$ 


\section{Constitutional Values and Public Administration}

Public administration is part of people's daily lives. Neither the state nor society can be imagined without governance. Public administration is a way of influencing public relations. Yu. A. Tikhomirov defines public administration as an organised process of management, regulation and control of state bodies over the development of economic and cultural spheres and other spheres of public life. ${ }^{9}$ This is the so-called broad approach to the definition of public administration. In the narrow sense of the word, public administration is a state-power activity of the executive authorities of the state to carry out their functions.

Public administration, in both the broad and narrow sense of the word, is based on the Constitution. ${ }^{10}$ Public administration is a kind of public-power activity. It is characterised by certain features. First, it is an activity that is managerial in nature. Secondly, it is carried out constantly and continuously. Third, it is a planned activity. Public administration is based on the principle of legality, i.e. it is carried out by the authorised state bodies established in the manner prescribed by law, using the methods provided by the law, within the limits defined by the law. Another important feature of public administration is the following. It is the management activity existing in the modern state and society, aimed at the achievement of generally significant results.

The role and importance of public administration is determined by the constitutional framework. Modern constitutions consider the idea of democracy as one of the basic principles of the organisation and functioning of the state and society. The people are the source of power in the state. Democracy means the sovereignty of the people. The people exercise their power either directly or through the state bodies they form. The direct forms of popular democracy are elections and referendum. The people or the body they have chosen to represent them determine the scope of powers of the subjects of public administration, the methods and limits of their implementation, as well as the range of issues that can be considered in a referendum. The constitutional character also has the definition of the sphere of activity of the self-government of the people. Self-government is implemented through a system of local self-government bodies, the composition of which may be different. The researchers identify today three main models of local government. ${ }^{11}$ The Anglo-Saxon model is characterised by a high degree of autonomy of local governments and the absence of special local government bodies. Local governments in the United Kingdom operate within the limits of the law, custom, established practice, judicial precedent, i.e. the unwritten Constitution, independently and under their own responsibility. The second model is the continental model, the classic example of which is France. One section of the French Constitution of $1958,{ }^{12}$ consisting of only one article - Article 72, is devoted to the issue of local self-government according to which "local communities of the Republic are communes, departments, overseas territories. All other local groups are formed by law". Collectives are freely managed by elected councils, but under conditions defined by the law. National interests, administrative control and law enforcement are the area of activity of government representatives in departments and territories. The same dual nature of the organisation of local government and self-government distinguishes the Republic of Belarus. Local administration and self-government in Belarus is exercised by 
citizens through local councils of deputies, executive and administrative bodies, and bodies of territorial public self-government (Article 117 of the Constitution). ${ }^{13}$ The combined model of organisation of local self-government is characteristic for Germany. In the Federal Republic of Germany, under Article 28 of the Basic Law, "communities shall be entitled to regulate all the affairs of the local community within the law under their own responsibility". ${ }^{14}$ Accordingly, the public administration in Germany is composed of areas with several communities that are community associations. The commune is the basic element of the whole mechanism of self-government. ${ }^{15}$ Public administration is a type of management system. This is a complex phenomenon, which includes the subjects, objects, goals, functions, legal and information support, the procedure for decision-making and execution. All components of public administration are determined by the Constitution, i.e. are set by the constitutional principles and norms. First, the subjects of public administration. The subjects of public administration in the broad sense of the word are individuals, public organisations, state bodies. If we consider public administration the implementation of its powers by state bodies, i.e. public administration in the narrow sense of the word, its subjects are the bodies of state power, empowered to exercise power and direct control of social processes. The state apparatus is numerous. Accordingly, the subjects of public administration may be classified on various grounds, many of which are constitutional in nature. The subjects of public administration are divided into legislative, executive and judicial branches of government. This basis of classification of state bodies is determined by Articles I, II and III of the Constitution of the United States, ${ }^{16}$ Article 10 of the Constitution of the Russian Federation, ${ }^{17}$ Article 6 of the Constitution of the Republic of Belarus. ${ }^{18}$ Public administration is divided into three parts: national, regional and local. The 3-element structure of the state apparatus is typical for federations, and 2-element structure - for unitary states. The forms of political-territorial organisations are defined by the Constitution of the state. The competence of state bodies is also established by constitutional norms. The above allows them to subdivide depending on the object of influence in leadership, administrative and economic field, etc. Fixed by the Constitution, the principle of decision-making entities of public administration is the basis of dividing them into single (individual) and collegial decision making.

The objects of public administration are the elements of the social environment and their relations, changing as a result of interaction with the subject of public administration. The specificity of various objects of public administration is determined by the fact that they all contain a "human factor". The objects of public administration are capable of self-movement, purposeful, adaptive, capable of self-government and dependent on the conditions of social life. These properties determine the methods, intensity and measure of influence on them of the subjects of public administration. The more developed the managed objects, the softer the public administration can be. In addition, according to the content determined by the social functions of objects, it is possible to distinguish objects management, distributed across the spheres of society. These are objects of economic, social, spiritual, political systems. Constitutions determine the foundations of the state and society, i.e. the constitutional system (otherwise, the state and social system). The structure of the constitutional system is characterised by economic, political, social, 
spiritual and ideological subsystems. Constitutional principles and norms determine the basis of each of the subsystems, direction, measure and limits of its regulation.

The purpose of public administration coincides with the purpose of the modern state and society. As such, it is expressly determined by part 1 of Article 2 of the Constitution of the Republic of Belarus, ${ }^{19}$ which states: "The person, his rights, freedoms and guarantees of their realization are the highest value and the goal of society and the state"; part 1 of Article 2 of the Constitution of the Russian Federation, ${ }^{20}$ according to which the person, his rights and freedoms are the highest value, and recognition, observance and protection of human and civil rights and freedoms - the duty of the state; Article 2 of the Constitution of Italy, ${ }^{21}$ according to which the Republic recognises and guarantees the inalienable rights of the human person as a private person and as a member of a public association in which his personality manifests itself, and requires the fulfilment of the immutable obligations arising from political, economic and social solidarity. According to the researchers, the legal aims of public administration should be distinguished. ${ }^{22}$ In socio-economic terms, the purpose of the activities of state bodies is the satisfaction of public interest and the economic well-being of the state and society. Public interest in this case is associated with the construction and maintenance of a certain system of economic relations. From a political point of view, it is the creation and functioning of a political system that would ensure the participation of all political forces of the state and society in the management of their affairs, that would contribute to human development. The security purpose of public administration is associated with ensuring public order and public security. The organisational and legal purpose - with the formation of a legal system that promotes the implementation of all functions of the state and society. It seems that all of these goals of public administration are the edge of one expected result, which state and society seeks - to ensure the rights and freedoms of the citizens. This constitutional goal, both the constitutional principle and the constitutional value, is embodied in many modern Constitutions, but more importantly, it is becoming both a basic and political value of society. Moreover - regardless of the state legal system. In modern realities, there is an increasing trend towards the international understanding of the values of the state and society.

The objectives of public administration are realised through its functions. Functions of public administration - the main activities of its subjects aimed at achieving the goals. The functions of the subjects of public administration reveal its essence. From the point of view of society and the state, the subjects of public administration implement such functions as setting goals and objectives, forecasting, planning, organising function, motivation function, regulation and control. As mentioned above, the objectives of public administration are directly determined by the Constitution. The same applies to the tasks of public administration. Among them - ensuring the internal and external security of the state, creating conditions for the development of democratic institutions of society, guaranteed protection of the rights and freedoms of citizens, the creation of equal legal conditions for the development of all forms of property, the formation of market mechanisms, ensuring mutually beneficial cooperation of central and local authorities.

The function of planning in public administration is expressed in setting goals, determining the necessary resources for their achievement, methods and terms, as well as forms 
and methods of step-by-step control over the activities of the control object, by which the implementation of the planned task is achieved.

The forecasting function in public administration is the development of a reasonable judgment about the future development of the company or its options, ways and terms of its achievement. The forecast is a reliable tool for making strategic management decisions.

The organisation as a function of public administration is to determine the organisational provisions establishing the order of management and procedural regulation: regulations, standards, instructions, requirements, responsibility, etc.

Motivation as a managerial function is usually considered in relation to limited, local systems. The motivation is not so much to form the motives of people's activities as to know, catch and form actions to guide the system in accordance with them. In case of public administration, the function of motivation is essentially the same, but differs in scale and content. Motivation at the national level takes the form of a national idea.

Regulation is an important function of modern public administration. It can be seen in a broad and narrow sense. The state, through the issuance of laws, regulations and judicial acts, establishes certain general rules of conduct for participants in public relations, i.e. regulates them.

The control function in public administration is designed to ensure discipline, legality, compliance with the regime of activity and the effectiveness of subjects and objects of public administration. In this regard, the control functions are connected with the state regulation to increase its efficiency.

The specific functions of public administration are embodied in the concrete manifestations of the whole variety of situations arising in practice, where it is necessary to act only on behalf of the state, realising its competence. These include the law enforcement function of judicial institutions, election and referendum commissions, state statistics (population census), licensing of activities, regulation of special legal regimes (state of emergency, free economic zones) and a number of others. These functions are based on the Constitution and must be subordinated to it.

The performance of functions by public administration actors is inextricably linked to the fundamental basic ideas underlying them and determining them. Constitutional legal principles - democracy, legality, separation of powers, unitarism (or federalism), etc. - are the basis of management activities, reveal its essence and act as a criterion for assessing their effectiveness. At the same time, not only the social and legal, but also the organisational principles of the subjects of state administration are determined by the Constitution. Sectoral and territorial principles, functional and linear, dual subordination and a combination of unity of command and collegiality all have a constitutional nature. Thus, the Constitution of the Republic of Belarus declares in part 1 of Article 1 that the Belarusian state is a democratic state and a unitary republic. ${ }^{23}$ According to Article 7 of the Basic Law, the principle of the rule of law is established in Belarus, one of the most important aspects of which is the action of the state, all its bodies and officials (subjects of state administration) within the framework of the Constitution and the legislative acts adopted in accordance with it. ${ }^{24}$ According to Article 1 of the Italian Constitution, democracy is the most important constitutional principle of the organisation and activities of the state, its bodies, officials and all subjects of law. ${ }^{25}$ Article 20, paragraph 1, of the Constitution of the Federal 
Republic of Germany enshrines both the principle of democracy and the principle of federalism. ${ }^{26}$

The legal basis of public administration is essentially determined by the Constitution. The basic law establishes the sources of law, builds their hierarchy. The normative basis of public administration in the conditions of the Republic of Belarus is the Constitution of the Republic of Belarus, laws adopted by the supreme representative body of the state - the National Assembly of the Republic of Belarus, the Belarusian Parliament, decrees and edicts of the President of the Republic of Belarus, other acts of state bodies issued on the basis and in accordance with the Basic Law of the Republic of Belarus.

In the organisation of public administration, the implementation of the functions of its subjects, the use of certain methods of their implementation, in the decision-making process and decision's execution may occur errors, distortions, deficiencies that have a negative impact on the order of social relations. Since constitutional principles and norms are the basis of this order, these errors should be considered a constitutional legal deformation. According to Nikitina A. V., constitutional deformations (or defects) are the shortcomings of legal regulation, interpretation and application of the law, leading to violation or threat of violation of constitutional principles and constitutional values. ${ }^{27}$

Constitutional deformations can be manifested in different ways and in different spheres of public administration. Therefore, it makes sense to highlight the constitutional deformation in the economic, political and social spheres. They can also be divided into deformations related to the organisation of state power and the legal status of the individual.

A constitutional deformation in the economic sphere, for example, related to the implementation of the most important constitutional principle of equality of state and private property, is the priority given to the protection of state property to the detriment of private property. Or withdrawal of the land plot by virtue of the interests of social necessity of private ownership or other lawful possession of the property of the state. An example of constitutional deformation in the political sphere is, for example, the illegal refusal to register a candidate or the refusal to register a political party that does not comply with the law.

Constitutional deformations are extremely diverse in their manifestations. One of the constitutional deformations, which is clearly manifested in modern States (especially in the territory of the former Soviet Union), is the establishment or reorganisation of state bodies or institutions, the needs of which are objectively absent. The lack of scientific forecasting in terms of the development of the state apparatus can generate a cyclical problem: the increase in the number of civil servants leads to an increase in the cost of their maintenance; from an economic point of view, this creates a need to reduce the number of officials; the reorganisation of the state apparatus leads to the emergence of new state structures and further on. The reform of the bureaucracy in modern states, carried out in line with legal reforms, often raises the question of duplication of powers of various state bodies, unclear definition of their competence, as well as difficulties in its differentiation. Hence - defects in the management system, including the legal regulation of social relations. Often, it is easier for an official not to take active actions than to justify their legitimacy in the future. The lack of initiative of the civil servants, their passivity can be regarded as another manifestation of constitutional deformation. 
Constitutional deformations in public administration undermine the authority of the law and threaten public order. Therefore, it seems necessary to determine the directions of their minimisation. The first direction is the optimisation of the functions and powers of bodies exercising public administration. Under the name of optimisation, A. L. Mironov understands the clarification of specific powers, the establishment of the exact responsibility of the controlled bodies for the execution of decisions, the strengthening of the financial and organisational basis of the control bodies. ${ }^{28}$ Another direction is training of professional civil servants. Moreover, it should be borne in mind that professionalism is not only deep knowledge and skills of officials, but also a high level of their moral and legal consciousness, based on the understanding and acceptance of human values. The application of sanctions for violations in the administration of public administration also appears to increase the responsibility of public servants for their decisions.

\section{Conclusion}

Thus, it is possible to draw the following conclusions:

Public administration as an organised process of management, regulation and control of state bodies over the development of economic and cultural spheres, other spheres of public life, and as the power activities of the executive bodies is based on the Constitution, obeys to it and is limited by it.

Subjects, objects, goals, functions, legal and information support, the process of decision-making and execution are determined by constitutional legal principles and norms.

When organising and in the process of functioning of the public administration, violations are possible, which are deviations from the constitutional legal principles and norms, i.e. constitutional legal deformations.

Constitutional legal deformations threaten public order and undermine the authority of the Constitution.

The methods aimed at preventing constitutional legal deformations are optimisation of functions and powers of the subjects of public administration, improvement of personnel work, strengthening control over the sphere of public administration and the use of legal responsibility, if necessary. 


\section{References}

1 Ю́рий Алекса́ндрович Тихоми́ров, Публиное право [Yuriy Alexandrovich Tikhomirov, Public law] (Moscow, BEK, 1995).

2 Ирина Алексеевна Василенко, Государственное и мунищипальное управление; Ирина Алексеевна Василенко, Государственное и муниципальное управление, 5-е изд. [Irina Alekseevna Vasilenko, State and municipal management] (Moscow, Yurayt, 2011); [Irina Alekseevna Vasilenko, State and municipal management] $5^{\text {th }}$ edition (Moscow, Yurayt, 2013).

3 Борис Аитвак, Государственное управление, Аучшие мировые практики [Boris Litvak, Governance - The world's best practices] (Moscow, Synergy, 2012).

4 Суре́н Адибе́кович Авакьян, Пробелы и дефекты в конституционном праве и пути их устранения, В кн. Пролемы и дефекты в конституционном праве и пути их устранения, Материалы международной научной конференции. Юридический факультет МГУ им. М.В.Аомоносова. Москва. 28-31 марта 2007 [Suren Adibekoviç Avakjan, Gaps and defects in constitutional law and ways of solving, 11-35, in Gaps and defects in constitutional law and ways of solving, Materials of international scientific conference, The Faculty of Law of the Moscow State University M. V. Lomonosov, March 28-31, 2007] (Moscow, Un-y, 2008).

5 Бондарь Николай Семенович, Местное самоуправление и конститущионное правосудие: конститущионализация мунищипальной демократии в России [Bondar Nikolai Semenovich, Local government and constitutional justice: constitutionalisation of the municipal democracy in Russia] (Moscow, Norma, 2008).

6 Игорь Александрович Кравец, Российский конститущионализм: проблемы становления, развития и осуществления [Igor Aleksandrovich Kravets, Russian constitutionalism: problems of formation, development and implementation] (Moscow, Legal Center Press, 2005).

7 ВАадимир Иванович Крусс, Констиущионализащия права: основы теории [Vladimir Ivanovich Kruss, Constitutionalisation of law: fundamentals of theory] (Moscow, Norma: Infra-M, 2017).

8 Алексей Алексеевич Аиверовский, О правопонимании в конституционной юстиции. Конститущионное и муниципальное право [Alexey Alekseevich Liverovskii, About the understanding of law in constitutional justice, 7-9, in Constitutional and Municipal Law, Moscow, № 6 (2015).

9 Юрий Алекса́ндрович Тихоми́ров, Публиное право [Yuriy Alexandrovich Tikhomirov, Public law] (Moscow, BEK, 1995).

10 There are different approaches to the definition of the Constitution: normative, natural-legal, politicallegal, etc. In this article, the author considers the Constitution a system of constitutional principles and norms enshrined in the Basic Law (or sources of law) of the state, defining the structure of the state and society.

11 Аанильян Олег Геннадійович, Местное самоуправление в Европейских странах: опыт и возможности его применения в Украине [Oleg Gennadyevich Danilyan, Local self-government in European countries: experience and opportunities of its application in Ukraine], www.rusnauka.com/17_AND_2010/ Politologia/69089.doc.htm (accessed 24 April 2018).

12 Конституция Франции 1958г. (The French Constitution of 1958), www.conseil-constitutionnel.fr/ conseil-constitutionnel/root/bank_mm/constitution/constitution_russe_version_aout2009.pdf (accessed 24 April 2018).

13 Конституция Республики Беларусь 15 марта 1994г. с изм. и доп., принятыми на республиканских референдумах 24 ноября 1996г. и 17 октября 2004г. [The Constitution of the Republic of Belarus of 1994: as amended and extended, adopted at the national referenda on 24 November 1996 and on 17 October 2004].

14 Основной Закон Федеративной Республики Германии, 23 мая 1949г. [Basic Law of the Federal Republic of Germany, May 23, 1949], www.1000dokumente.de/?c=dokument_de\&dokument=0014 gru\&object $=$ translation\&l=ru (accessed 03 May 2018). 
15 Наталья ВАадимировна Михалева, Местное самоуправление в Германии, Аенинградский юридический журнал [Natalya Vladimirovna Mikhaleva, Local self-government in Germany, 177-185, in The Leningrad Law Journal (2013).]

16 Конституция Соединенных Штатов Америки 1787 года [The Constitution of the United States of America, 1787], www.hist.msu.ru/ER/Etext/cnstUS.htm (accessed 03 May 2018).

17 Конституция Российской Федерации от 12 декабря 1993г.: офиц.текст: М.:Юрист, 2005, 56. [ТТе Constitution of the Russian Federation from December 12, 1993; official text: M.: Lawyer, 2005, 56.]

18 Конституция Республики Беларусь 15 марта 1994г. с изм. и доп., принятыми на республиканских референдумах 24 ноября 1996г. и 17 октября 2004г. [The Constitution of the Republic of Belarus of 1994: as amended and extended, adopted at the national referenda on 24 November 1996 and on 17 October 2004.]

19 Ibid.

20 Конституция Российской Федерации от 12 декабря 1993г.: офиц.текст: М.:Юрист, 2005, 56. [ТТе Constitution of the Russian Federation from December 12, 1993; official text: M.: Lawyer, 2005, 56.]

21 Конституция Итальянской Республики от 22 декабря 1947г. [The Constitution of the Italian Republic of 22 December 1947], http://lawers-ssu.narod.ru/subjects/constzs/italy.htm (accessed 03 May 2018).

22 Сергей Наумов, Ирина Осипова, Анна Подсумкова, Система государственного управления [Sergey Naumov, Irina Osipova, Anna Podsumkova, The System of public administration] (Moscow, Forum, 2008).

23 Конституция Республики Беларусь 15 марта 1994г. с изм. и доп., принятыми на республиканских референдумах 24 ноября 1996г. и 17 октября 2004г. [The Constitution of the Republic of Belarus of 1994: as amended and extended, adopted at the national referenda on 24 November 1996 and on 17 October 2004.]

24 Ibid.

25 Конституция Итальянской Республики от 22 декабря 1947г. [The Constitution of the Italian Republic of 22 December 1947], http://lawers-ssu.narod.ru/subjects/constzs/italy.htm (accessed 03 May 2018).

26 Основной Закон Федеративной Республики Германии, 23 мая 1949г. [Basic Law of the Federal Republic of Germany, May 23, 1949], www.1000dokumente.de/?c=dokument_de\&dokument $=0014$ gru\&object $=$ translation\&l=ru (accessed 24 April 2018).

27 Анна Васильевна Никитина, Понятие и виды конституционных дефектов, Актуальньц вопросы юридических наук: Материалы III МежАунар. науч. конф. (г.Чита, апрель 2017г.) [Anna Vasilyevna Nikitina, Concept and types of constitutional defects, actual problems of legal science, Proceedings of the $3^{\text {rd }}$ International Scientific Conference, April 2017] (Chita, Publishing House of the Young Scientist, 2017, 40-45.]

28 Артур Миронов, Государственное управление: критерии оценки эффективности и направления реформирования, Вестник Московского университета МBA России [Artur Mironov, Public administration: criteria for evaluating the effectiveness and direction of reform, 67-70, in Bulletin of the Moscow University of the Ministry of Internal Affairs of Russia, № 11 (2015).] 